\title{
ANALISIS KADAR MINERAL DALAM ABU BUAH NIPA (NYPA FRUCTICANS) KALIWANGGU TELUK KENDARI SULAWESI TENGGARA
}

\author{
Herman $^{1)}$, Rolan Rusli $^{1)}$, Edi Ilimu ${ }^{2)}$, Rimba Hamid $^{2)}$, Haeruddin $^{2)}$ \\ Kelompok Bidang Ilmu Kimia Farmasi, Fakultas Farmasi, Universitas Mulawarman, Samarinda) ${ }^{1}$ \\ e-mail :rolan@farmasi.unmul.ac.id \\ Program Studi Pendidikan Kimia, FKIP, Universitas Haluoleo, Kendari, Sultra) ${ }^{2}$
}

\begin{abstract}
Research about Levels of ash analysis in Nipa Fruit (Nypa fructicans) Kaliwanggu Kendari Gulf South East Sulawesi have been done. Research carried out by gravimetric method and $A A S$. The ash content of old nipa fruit at a temperature $450^{\circ} \mathrm{C}$ dan $550^{\circ} \mathrm{C}$ obtained amounted to $1.01 \%$ and $0.89 \%$. while the young nipa fruits obtained ash content of $0.88 \%$ and $0.86 \%$ at $450^{\circ} \mathrm{C}$ dan $550^{\circ} \mathrm{C}$. Mineral content of old nipa fruit which had become ash at a temperature of $450^{\circ} \mathrm{C}$ obtained at $1.3769 \mathrm{ppm}, 7.9167 \mathrm{ppm}, 3.7876 \mathrm{ppm}, 9.2365 \mathrm{ppm}$, respectively for $\mathrm{Fe}$, $\mathrm{Mg}, \mathrm{K}$, and $\mathrm{Na}$. On the other hand, at a temperature of $550^{\circ} \mathrm{C}$ obtained at $1.1153 \mathrm{ppm}, 8.0127$ ppm, 3.7990 ppm and 9.3634 ppm, respectively for $\mathrm{Fe}, \mathrm{Mg}, \mathrm{K}$, and $\mathrm{Na}$. On young fruit nipah obtained concentration of 0.8769 ppm, 7.9939 ppm, 3.8260 ppm, 9.4041 ppm, respectively for $\mathrm{Fe}, \mathrm{Mg}, \mathrm{K}$, and $\mathrm{Na}$ at ash temperature $450^{\circ} \mathrm{C}$. Meanwhile, at a ash temperature of $550^{\circ} \mathrm{C}$ obtained concentration of $0.9230 \mathrm{ppm}, 7.9738 \mathrm{ppm}, 3.7468 \mathrm{ppm}$ and $9.3861 \mathrm{ppm}$, respectively for $\mathrm{Fe}, \mathrm{Mg}, \mathrm{K}$, and $\mathrm{Na}$. The water content obtained from the old and young nipa flesh fruit obtained at $41.86 \%$ and $33.49 \%$, respectively.
\end{abstract}

Key words: Level of mineral analysis, Nypa fructicans, Gravimetric, AAS

\begin{abstract}
ABSTRAK
Telah dilakukan penelitian dengan judul "Analisis Kadar dalam Abu Buah Nipa (Nypa fructicans)" Kaliwanggu Teluk Kendari Sulawesi Tenggara. Penelitian dilakukan dengan metode gravimetri dan AAS. Kadar abu buah nipa tua pada suhu $450^{\circ} \mathrm{C}$ dan $550^{\circ} \mathrm{C}$ diperoleh sebesar $1,01 \%$ dan $0,89 \%$, sedangkan pada buah nipa muda diperoleh kadar abu sebesar $0,88 \%$ dan $0,86 \%$ berurut-turut untuk suhu $450^{\circ} \mathrm{C}$ dan $550^{\circ} \mathrm{C}$. Kadar mineral buah nipa tua yang diabukan pada suhu $450^{\circ} \mathrm{C}$ diperoleh sebesar $1,3769 \mathrm{ppm}, 7,9167 \mathrm{ppm}, 3,7876 \mathrm{ppm}$, 9,2365 ppm, berturut-turut untuk Fe, $\mathrm{Mg}, \mathrm{K}$, dan $\mathrm{Na}$. Sedangkan pada suhu $550^{\circ} \mathrm{C}$ diperoleh sebesar 1,1153 ppm, 8,0127 ppm, 3,7990 ppm, dan 9,3634 ppm, berturut-turut untuk Fe, $\mathrm{Mg}$, $\mathrm{K}$, dan Na. Pada buah nipa muda diperoleh kadar sebesar 0,8769 ppm, 7,9939 ppm, 3,8260 ppm, 9,4041 ppm, berturut-turut untuk $\mathrm{Fe}, \mathrm{Mg}, \mathrm{K}$, dan $\mathrm{Na}$ pada suhu pengabuan $450^{\circ} \mathrm{C}$. Sedangkan pada suhu pengabuan $550^{\circ} \mathrm{C}$ diperoleh kadar sebesar 0,9230 ppm, 7,9738 ppm, 3,7468 ppm, dan 9,3861 ppm, berturut-turut untuk Fe, Mg, K, dan Na. Adapun kadar air yang diperoleh dari daging buah nipa tua dan muda diperoleh sebesar $41,86 \%$ dan $33,49 \%$.
\end{abstract}

Kata kunci: Analisis kadar mineral, Nypa fructicans, Gravimetri, AAS 


\section{PENDAHULUAN}

Sulawesi Tenggara adalah salah satu propinsi yang terdiri dari beberapa Kabupaten dan Kota yang terdistribusi dalam beberapa pulau. Sebagai propinsi yang terdiri dari gugusan pulau tersebut, maka Sulawesi Tenggara memiliki daerah pesisir yang luas. Daerah pesisir memiliki berbagai keanekaragaman hayati. Potensi terbesar dari keanekaragaman hayati yang terdapat di daerah pesisir adalah ekosistem Mangrove.

Mangrove adalah vegetasi hutan yang tumbuh diantara garis pasang surut. Beberapa manfaat vegetasi Mangrove yaitu penahan abrasi dan gelombang serta pemanfaatan hasil hutan Mangrove bagi masyarakat misalnya sebagai penghasil kayu, obat-obatan, dan lain-lain. Tiga jenis tumbuhan yang biasa dijumpai pada ekosistem Mangrove adalah tanaman acanthus, acrostichum dan palm yang tidak berbatang atau yang biasa dikenal dengan nama nipa [1].

Nipa merupakan salah satu vegetasi Mangrove yang banyak tumbuh di daerah pesisir Sulawesi Tenggara. Pemanfaatan nipa selama ini adalah daunnya digunakan untuk bahan atap, selaput tembakau rokok, dan nira dari sadapan pembuangannya digunakan untuk pembuatan gula dan alkohol [2]. Selain itu juga dapat digunakan sebagai obat tradisional seperti asma, diabetes, rematik, dan gigitan ular [3].

Pemanfaatan nipa oleh masyarakat di daerah Sulawesi Tenggara belum optimal. Salah satu potensi dari tumbuhan nipa yang belum dimanfaatkan adalah buah nipa. Sebagai tumbuhan berjenis palm, maka buah nipa memiliki kandungan karbohidrat, abu, air, energi, protein dan asam lemak [4].
Bentuk pemanfaatan buah nipa dijadikan sebagai salah satu bahan makanan olahan seperti dibuat kolak, kolang kaling, manisan dan air sadapannya dapat dibuat gula merah. Daging buah nipa muda dapat dimanfaatkan sebagai bahan baku minuman es buah. Nipa termasuk minuman istimewa pada restoran di Distrik Taiping, Negeri perak Malaysia. Selain itu, di Pantai Timur Sumatera Utara (Langkat-Deli Serdang) pada bulan puasa ramadhan, masyarakat memanfaatkan buah nipa muda sebagai bahan baku makanan kolak [5].

Kandungan gizi makanan bahan baku tumbuhan nipa sebagai salah satu sumber bahan makanan perlu dikembangkan lebih lanjut terutama sehubungan dengan bahan makanan nantinya. Sebagaimana layaknya bahwa makanan mengandung zat-zat tertentu yang ada kaitannya dengan pertumbuhan dan perkembangan hidup manusia itu sendiri. Dalam buah nipa terdapat zat-zat pangan yang diperlukan untuk mencukupi kebutuhan zat-zat makanan dalam tubuh manusia, namun informasi mengenai kandungan mineralmineral dari buah nipa belum dilaporkan secara ilmiah.

Berdasarkan uraian tersebut maka dilakukan penelitian untuk mengetahui zatzat gizi yang terdapat dalam buah nipa khususnya mineral buah nipa tersebut.

\section{TUJUAN PENELITIAN}

Tujuan penelitian ini adalah untuk memperoleh data tentang kadar abu, kadar air dan kadar mineral besi ( $\mathrm{Fe})$, magnesium $(\mathrm{Mg})$, kalium $(\mathrm{K})$, dan natrium $(\mathrm{Na})$ yang terdapat dalam buah nipa (Nypa Fructicans) tua dan muda. 


\section{METODE}

Penentuan Kadar Abu (Metode Dry Ashing) [6]

Cawan yang telah dibersihkan dipanaskan dalam tanur pada suhu $100-105^{\circ} \mathrm{C}$ selama 3 jam lalu ditimbang sebagai bobot kosong. Contoh yang telah diuapkan ditimbang teliti \pm 5 gram dan dinyatakan sebagai bobot awal, kemudian cawan tersebut disimpan dalam tanur pada suhu $550^{\circ} \mathrm{C}$ selama 6 jam. Setelah pemanasan cawan dimasukan dalam desikator dan setelah dingin ditimbang sampai diperoleh bobot tetap sebagai bobot akhir.

$$
\begin{aligned}
& \text { Kadar abu }=\frac{c-a}{b-a} \times 100 \% \\
& \begin{aligned}
\text { Ket. } \quad: \\
\mathrm{a}=\text { bobot cawan kosong } \\
\mathrm{b}=\text { bobot cawan dan contoh } \\
\mathrm{c}=\text { bobot cawan dan contoh setelah pengabuan }
\end{aligned}
\end{aligned}
$$

\section{Penentuan Kadar Air Sampel [7]}

Cawan yang bersih beserta tutupnya dipanaskan dalam oven pada suhu 100$105^{\circ} \mathrm{C}$ selama 3 jam. Dengan menggunakan gegep, cawan ditutup dan didinginkan dalam desikator selama 15 menit, kemudian cawan ditimbang (Co). selanjutnya, sampel sebanyak 5 gram dimasukkan kedalam cawan dan ditimbang bersama tutupnya (Cb), kemudian dipanaskan dalam oven selama 3 jam, lalu didinginkan dalam eksikator selama 15 menit kemudian ditimbang (Ck). Perlakuan ini dilakukan berulang-ulang sampai diperoleh berat yang konstan.

$$
\text { Kadar air }=\frac{(C b-C o)-(C k-C o)}{C b-C o} \times 100 \%
$$

Keterangan :

$$
\begin{aligned}
& \mathrm{Co}=\text { berat cawan kosong }(\mathrm{g}) \\
& \mathrm{Cb}=\text { berat cawan dengan sampel basah }(\mathrm{g}) \\
& \mathrm{Ck}=\text { berat cawan dengan sample kering }(\mathrm{g})
\end{aligned}
$$

\section{Pengujian Logam dengan metode Spektrofotometer Serapan Atom (SSA)}

\section{a. Tahap Destruksi Kering}

Masing-masing sebanyak 5 gram sampel buah nipa tua dan muda yang telah diparut halus, diuapkan dalam oven pada suhu $105^{\circ} \mathrm{C}$ selama 45 menit, didesikator selama 15 menit, kemudian diabukan dalam tanur dengan variasi suhu $450^{\circ} \mathrm{C}$ dan $550^{\circ} \mathrm{C}$ selama 6 jam sampai mengering hingga diperoleh sampel yang menjadi abu. Selanjutnya dilakukan analisis kandungan mineral dengan spektrofotometer serapan atom.

\section{b. Pembuatan Larutan Standar}

\section{Larutan Standar Fe}

Larutan stok primer besi 100 ppm. Dari larutan ini dipipet masing-masing $0,5 \mathrm{~mL}$; $1 \mathrm{~mL} ; 1,5 \mathrm{~mL}$; dan $2 \mathrm{~mL}$ ke dalam labu ukur $25 \mathrm{~mL}$ dan diencerkan dengan aquabides sehingga didapatkan larutan uji 2 ppm; 4 ppm; 6 ppm; dan 8 ppm.

\section{Larutan Standar Mg}

Larutan stok primer magnesium $100 \mathrm{ppm}$. Larutan ini dipipet masing-masing 0,0625 $\mathrm{mL} ; 0,125 \mathrm{~mL} ; 0,5 \mathrm{~mL} ; 1 \mathrm{~mL} ; 1,5 \mathrm{~mL}$ dan $2 \mathrm{~mL}$ ke dalam labu ukur $25 \mathrm{~mL}$ dan diencerkan dengan aquabides, sehingga didapatkan larutan uji 0,25 ppm; 0,5 ppm; 2 ppm; 4 ppm; 6 ppm; dan 8 ppm.

\section{Larutan Standar K}

Larutan stok primer kalium 100 ppm. Dari larutan ini dipipet masing-masing 0,125 $\mathrm{mL} ; 0,25 \mathrm{~mL} ; 0,375 \mathrm{~mL}$; dan $0,5 \mathrm{~mL}$ ke dalam labu ukur $25 \mathrm{~mL}$ dan diencerkan dengan aquabides sehingga didapatkan larutan uji 0,5 ppm; 1 ppm; 1,5 ppm; dan 2 ppm. 


\section{Larutan Standar Na}

Larutan stok primer natrium $100 \mathrm{ppm}$. Dari larutan ini dipipet masing-masing $0,5 \mathrm{~mL}$; $1 \mathrm{~mL} ; 1,5 \mathrm{~mL}$; dan $2 \mathrm{~mL}$ ke dalam labu ukur $25 \mathrm{~mL}$ dan diencerkan dengan aquabides sehingga didapatkan larutan uji 2 ppm; 4 ppm; 6 ppm; dan 8 ppm.

\section{Penentuan Kadar Mineral Unsur dengan Spektro-fotometer Serapan Atom (SSA)}

Sampel buah nipa tua dan muda yang telah menjadi abu masing-masing pada suhu $450^{\circ} \mathrm{C}$ dan $550^{\circ} \mathrm{C}$, ditambahkan $10 \mathrm{~mL}$ $\mathrm{HCl} 10 \mathrm{M}$, kemudian dipanaskan diatas hot plate sampai abu larut.
Abu yang telah larut dipindahkan dalam labu takar $100 \mathrm{~mL}$ dan diencerkan dengan $\mathrm{HNO}_{3} 0,1 \mathrm{M}$ sampai batas tera. Selanjutnya contoh /sampel dan larutan standar siap dibaca pada alat spektrofotometer serapan atom pada panjag gelombang 248,3 nm untuk Fe; 285,2 nm untuk $\mathrm{Mg} ; 766,5 \mathrm{~nm}$ untuk K; dan 589 nm untuk Na.

\section{HASIL DAN PEMBAHASAN}

Kadar abu buah nipa disajikan pada Tabel 1., sedangkan Kadar mineral buah nipa untuk logam besi, Magnesium, Kalium, dan Natrium disajikan pada Tabel 2., dan untuk kadar air disajikan pada Tabel 3.

Tabel 1. Kadar Abu Sampel Buah Nipa

\begin{tabular}{cccccccc}
\hline \multirow{2}{*}{ No. } & \multirow{2}{*}{ Sampel } & \multirow{2}{*}{$\begin{array}{c}\text { Suhu } \\
\left({ }^{\circ} \mathrm{C}\right)\end{array}$} & \multicolumn{6}{c}{ Ulangan } & \multirow{2}{*}{ Rerata } \\
\cline { 5 - 6 } & & 450 & 0,99 & 0,90 & 1,22 & 0,92 & 1,01 \\
1. & \multirow{2}{*}{ Tua } & $4 \mathrm{I}$ & III & IV & \\
3. & & 550 & 0,90 & 0,88 & 0,90 & 0,90 & 0,89 \\
4. & \multirow{2}{*}{ Muda } & 450 & 0,88 & 0,89 & 0,88 & 0,89 & 0,88 \\
& & 550 & 0,81 & 0,86 & 0,88 & 0,91 & 0,86 \\
\hline
\end{tabular}

Tabel 2. Kadar Mineral Sampel Buah Nipa

\begin{tabular}{ccccccc}
\hline \multirow{2}{*}{ No. } & \multirow{2}{*}{ Sampel } & \multirow{2}{*}{$\begin{array}{c}\text { Suhu } \\
\left({ }^{\circ} \mathrm{C}\right)\end{array}$} & \multicolumn{4}{c}{ Konsentrasi Mineral $(\mathrm{ppm})$} \\
\cline { 4 - 7 } & & & Besi & Magnesium & Kalium & Natrium \\
\hline 1. & Tua & 450 & 1,3769 & 7,9167 & 3,7876 & 9,2365 \\
2. & Muda & 450 & 0,8769 & 7,9939 & 3,8260 & 9,4041 \\
3. & Muda & 550 & 0,9230 & 7,9738 & 3,7468 & 9,3861 \\
4. & Tua & 550 & 1,1153 & 8,0127 & 3,7990 & 9,3634 \\
\hline
\end{tabular}

Tabel 3. Kadar Abu Sampel Buah Nipa

\begin{tabular}{cccccc}
\hline \multirow{2}{*}{ No. } & \multirow{2}{*}{ Sampel } & \multicolumn{3}{c}{ Ulangan } & \multirow{2}{*}{ Rerata } \\
\cline { 3 - 5 } & & I & II & III & \\
\hline 1. & Tua & 42,21 & 42,98 & 40,38 & 41,86 \\
2. & Muda & 30,82 & 34,33 & 35,33 & 33,49 \\
\hline
\end{tabular}

\section{PEMBAHASAN}

Kadar abu dalam bahan pangan menunjukkan jumlah mineral yang dikandung dalam bahan pangan tersebut.
Prinsip kerja penentuan kadar abu diawali dengan cara membakar bahan pangan tersebut. Prinsip kerja penentuan kadar abu diawali dengan cara membakar bahan 
pangan dalam tungku pengabuan (furnace) dengan memvariasikan suhu pemanasan sampai mendapatkan abu yang berwarna putih. Penetapan bobot abu dihitung berdasarkan gravimetri [6].

Data hasil analisis kadar abu buah nipa muda pada suhu $450^{\circ} \mathrm{C}$ sebesar $1,01 \%$ sedangkan suhu $550^{\circ} \mathrm{C}$ sebesar $0,89 \%$. Kadar abu yang terkandung didalam sampel nipa tua juga mengalami penurunan yakni $0,88 \%$ pada suhu $450^{\circ} \mathrm{C}$ menjadi $0,86 \%$ pada suhu $550^{\circ} \mathrm{C}$. Penurunan kadar abu ini disebabkan oleh berkurangnya mineral yang terdegradasi oleh pengaruh suhu dalam sampel buah nipa. Hal ini sebagaimana yang diungkapkan Winarno [8], pada suhu pengabuan yang rendah, panas yang diterima oleh bahan hanya dapat mengabukan sebagian mineral yang ada di permukaan, sehingga penurunan kadar abu bahan relatif kecil. Sedangkan pada suhu pengeringan yang lebih tinggi dengan waktu yang lebih lama, panas yang diterima oleh bahan selain digunakan untuk mengabukan mineral pada permukaan bahan, juga dapat mengabukan mineral yang terikat di dalam bahan. Dari tabel 8 diperoleh bahwa kadar abu nipa tua lebih tinggi dibandingkan dengan nipa muda, hal ini disebabkan pada nipa tua volume daging buah yang terbentuk sudah mengalami proses pengerasan dan memiliki jumlah mineral yang lebih banyak.

Berdasarkan Tabel 2 terlihat bahwa konsentrasi logam besi (Fe) pada sampel buah nipa tua yang dianalisis dengan AAS pada suhu $450^{\circ} \mathrm{C}$ adalah $1,3769 \mathrm{ppm}$. Sedangkan pada suhu $550^{\circ} \mathrm{C}$ konsentrasi Logam $\mathrm{Fe}$ menjadi lebih rendah yaitu sebesar 1,1153 ppm.

Hal ini disebabkan karena logam besi mempunyai titik didih yang hampir sama dengan $450^{\circ} \mathrm{C}$ atau berkisar antara 400 - $500^{\circ} \mathrm{C}$, sehingga kadar besi atau konsentrasi besi yang didapatkan dengan hasil analisis pada suhu tersebut akan semakin tinggi konsentrasinya.

Sedangkan pada suhu di atas $500^{\circ} \mathrm{C}$, ini akan menyebabkan besi yang terkandung dalam sampel buah nipa sebagian akan menguap yang diakibatkan oleh suhu yang terlampau tinggi sehingga besi yang diperoleh akan sangat sedikit.

Pada sampel buah nipa muda pada suhu $450^{\circ} \mathrm{C}$, konsentrasi besinya adalah sebesar $0,8769 \mathrm{ppm}$. Sedangkan pada suhu $550^{\circ} \mathrm{C}$, konsentrasinya sebesar $0,9230 \mathrm{ppm}$. Selain itu, Sediaoetama [9] menyatakan bahwa abu dalam bahan makanan adalah sisa pembakaran sempurna dari suatu bahan makanan yang menggambarkan banyaknya mineral yang tidak terbakar menjadi zat yang dapat menguap. Berdasarkan pada pernyataan tersebut maka kadar besi pada buah nipa tua pada suhu $450^{\circ} \mathrm{C}$ memiliki kadar yang tinggi sedangkan pada suhu $550^{\circ} \mathrm{C}$ kadarnya rendah karena pada suhu $550^{\circ} \mathrm{C}$ tersebut, ion besinya sudah menguap sehingga kadar besi dari buah nipa tua pada suhu $550^{\circ} \mathrm{C}$ tersebut lebih kecil dari kadar besi pada suhu $450^{\circ} \mathrm{C}$.

Untuk konsentrasi logam Magnesium (Mg) pada sampel buah nipa tua pada suhu $450^{\circ} \mathrm{C}$ adalah $7,9167 \mathrm{ppm}$ dan pada suhu $550^{\circ} \mathrm{C}$ sebesar 8,0127 ppm. Sedangkan sampel buah nipa muda pada suhu $450^{\circ} \mathrm{C}$, konsentrasi magnesiumnya sebesar 7,9939 ppm dan pada suhu $550^{\circ} \mathrm{C}$, sebesar 7,9738 ppm.

Hal ini diakibatkan magnesium yang terdapat pada tumbuhan yang muda maupun yang tua kadarnya tidak jauh berbeda, atau dengan kata lain kadar magnesium yang ada dalam tumbuhan tidak mengalami oksidasi ataupun reaksi dengan zat-zat lain yang ada di luar 
lingkungan logam itu sendiri. Ini dapat dilihat dari perbedaan tiap kadar magnesium yang dianalisis pada suhu yang berbeda yakni $450^{\circ} \mathrm{C}$ dan $550^{\circ} \mathrm{C}$ menunjukkan kadar yang sangat berdekatan yakni yang terjadi pada buah nipa muda yang diukur pada serapan suhu $450^{\circ} \mathrm{C}$ dan $550^{\circ} \mathrm{C}$ hanya berbeda kadarnya sekitar 0,002 ppm. Begitu pula halnya pada buah nipa tua kadar dari magnesium hanya mencapai perbedaan sekitar 0,1 ppm,. Fakta ini menunjukkan bahwa kadar magnesium baik yang terdapat pada buah nipa yang muda maupun yang tua hampir menunjukkan kadar yang sama.

Konsentrasi logam Kalium (K) pada sampel buah nipa tua pada suhu $450^{\circ} \mathrm{C}$ adalah sebesar 3,7876 ppm, dan pada suhu $550^{\circ} \mathrm{C}$ sebesar $3,7990 \mathrm{ppm}$. Sedangkan buah nipa muda pada suhu $450^{\circ} \mathrm{C}$, konsentrasi kaliumnya adalah sebesar 3,8260 ppm dan pada suhu $550^{\circ} \mathrm{C}$, sebesar 3,7468 ppm. Hal ini disebabkan karena titik didih dari logam Kalium sekitar $759^{\circ} \mathrm{C}$, ini berarti keadaan yang hampir mendekati pada saat pengukuran dengan AAS adalah dengan pengukuran pada suhu $550^{\circ} \mathrm{C}$. dengan pengukuran yang demikian maka jumlah konsentrasi Kalium yang ada akan mendekati keadaan yang semestinya, berbeda dengan saat pengukuran pada suhu $450^{\circ} \mathrm{C}$ dan suhu $550^{\circ} \mathrm{C}$, yang menunjukkan bahwa pada buah yang muda konsentrasi dari masing-masing sampel buah muda berada di bawah dari buah yang tua. Hal ini diakibatkan karena suhu dari logam Kalium masih jauh dari titik didihnya.

Untuk logam Natrium (Na) pada sampel buah nipa tua pada suhu $450^{\circ} \mathrm{C}$ diperoleh konsentrasi sebesar 9,2365 ppm, dan pada suhu $550^{\circ} \mathrm{C}$ sebesar 9,3634 ppm. Sedangkan buah nipa muda pada suhu $450^{\circ} \mathrm{C}$, konsentrasi natriumnya sebesar $9,4041 \mathrm{ppm}$, dan pada suhu $550^{\circ} \mathrm{C}$, sebesar 9,3861 ppm.
Hal ini menunjukkan bahwa kadar Natrium dari tumbuhan buah nipa baik yang tua maupun yang muda ketika diukur pada serapan dengan menggunakan 2 tingkatan suhu yang berbeda akan menunjukkan hasil yang tidak jauh berbeda. Keadaan ini memberikan informasi bahwa kadar natrium dari buah nipa yang muda maupun yang tua tidak berbeda signifikan. Ini dapat dilihat dari nilai kadar dari natrium sendiri yang sangat berdekatan, dimana buah yang muda ketika diukur dengan menggunakan AAS pada suhu $450^{\circ} \mathrm{C}$ dan suhu $550^{\circ} \mathrm{C}$ menunjukkan kadar yang hampir sama yakni dengan perbedaan kadar 0,1 ppm.

Sedangkan untuk yang buah tua yang diukur dengan menggunakan alat yang sama dan pada suhu yang sama pula menunjukkan perbedaan kadar atau konsentrasi yang tidak jauh berbeda, dengan kadar konsentrasi dari buah tua pada suhu $450^{\circ} \mathrm{C}$ sekitar $9,2365 \mathrm{ppm}$ dan pada suhu $550^{\circ} \mathrm{C}$ sekitar 9,3634 ppm. Fakta ini menunjukkan bahwa kadar konsentrasi dari Natrium yang ada dalam tidak mengalami perubahan yang signifikan, tetapi tergantung dari adanya tekanan atau suhu dari proses pengukuran.

Analisis kadar air digunakan untuk mengetahui kandungan air pada daging buah nipa dengan cara pengeringan (thermogravimetri). Kadar air merupakan banyaknya air yang terkandung dalam bahan yang dinyatakan dalam persen. Kadar air juga salah satu karakteristik yang sangat penting pada bahan pangan, karena air dapat mempengaruhi penampakan, tekstur, dan citarasa pada bahan pangan. Kadar air dalam bahan pangan ikut menentukan kesegaran dan daya awet bahan pangan tersebut, kadar air yang tinggi mengakibatkan mudahnya bakteri, kapang, dan khamir untuk berkembang biak, sehingga akan terjadi perubahan pada bahan pangan [8]. 
Dari Tabel 3 terlihat bahwa rata-rata kadar air yang terkandung dalam daging buah nipa tertinggi ialah kadar air daging buah nipa tua yaitu sebanyak $41,86 \%$ dan yang terendah pada daging buah nipa muda yaitu sebanyak 33,49\%. Rata-rata kadar air daging buah nipa ini didapatkan setelah dilakukan pengukuran kadar air tiga kali berturut-turut yaitu $42,21 \%, 42,98 \%$ dan $40,38 \%$. Rerata kadar air daging buah nipa muda juga dilakukan sebanyak tiga kali dan didapatkan hasil kadar air buah nipa muda berturut-turut yaitu 30,82\%, 34,33\% dan $35,33 \%$.

Kandungan air yang terkandung pada daging buah nipa tua lebih banyak dibandingkan daging buah nipa muda. Kandungan air bahan makanan pada umumnya menunjukkan bahwa banyaknya air dalam suatu bahan tidak dapat ditentukan dari keadaan fisik bahan makanan itu saja. Pada daging buah nipa tua dapat terlihat secara kasat mata bahwa banyaknya air yang terkandung dalam jumlah kecil. Namun setelah dilakukan analisis kadar air, daging buah nipa tua lebih banyak mengandung air dibandingkan pada daging buah nipa muda yang secara kasat mata memiliki kandungan air yang besar ternyata memiliki kandungan air yang lebih kecil.

\section{KESIMPULAN}

Berdasarkan hasil uraian di atas, dapat disimpulkan sebagai berikut:

1. Rerata kadar abu yang terkandung dalam daging buah nipa tertinggi ialah kadar abu daging buah nipa tua pada suhu $450^{\circ} \mathrm{C}$ yaitu sebanyak $1,01 \%$ dan yang terendah pada daging buah nipa muda pada suhu $550^{\circ} \mathrm{C}$ yaitu sebanyak $0,86 \%$.

2. Rerata kadar air yang terkandung dalam daging buah nipa tertinggi ialah kadar air daging buah nipa tua yaitu sebanyak $41,86 \%$ dan yang terendah pada daging buah nipa muda yaitu sebanyak $33,49 \%$.

3. Jumlah kandungan kadar $\mathrm{Fe}, \mathrm{Mg}, \mathrm{K}$, dan Na pada buah nipa tua pada suhu $450^{\circ} \mathrm{C}$ yakni 1,3769 ppm untuk $\mathrm{Fe}$, 7,9167 ppm untuk $\mathrm{Mg}, 3,7876 \mathrm{ppm}$ untuk $\mathrm{K}, 9,2365 \mathrm{ppm}$ unutk $\mathrm{Na}$ dan pada suhu $550^{\circ} \mathrm{C}$ yakni $1,1153 \mathrm{ppm}$ untuk $\mathrm{Fe}, 8,0127 \mathrm{ppm}$ untuk $\mathrm{Mg}$, 3,7990 ppm untuk K dan 9,3634 ppm untuk Na. Sedangkan pada buah nipa muda pada suhu $450^{\circ} \mathrm{C}$ yakni 0,8769 ppm untuk Fe, 7,9939 ppm untuk Mg, 3,8260 untuk K, 9,4041 ppm untuk Na dan pada suhu $550^{\circ} \mathrm{C}$ yakni 0,9230 ppm untuk Fe, 7,9738 ppm untuk $\mathrm{Mg}$, 3,7468 ppm untuk K, dan 9,3861 ppm untuk Na.

\section{DAFTAR PUSTAKA}

1. Stenis, C. G. G. G. V. 2005, Flora. Pradaya Paramita; Jakarta.

2. Kashiko, T. 2004, Kamus Lengkap Biologi. Kashiko Press; Surabaya.

3. Setyawan, A. D.; \& Winarno, K. 2006, Pemanfaatan Langsung Ekosistem Mangrove di Jawa Tengah dan Penggunaan Lahan di Sekitarnya; Kerusakan dan Upaya Restorasinya. Biodiversitas. 7. 282-291.

4. Azuma, H.; Toyota, M.; Asakawa, Y.; Takaso, T.; \& Tobe, H. 2002, Floral Scent Chemistry of Mangrove Plants. J. Plant. Res. 115. 47-53.

5. Bandaranayake, W. M. 1998, Traditional and medicinal uses of mangroves. Mangroves and Salt Marshes. 2. 133-148.

6. Apriyanto A, dkk., 1989. Analisis Pangan. Departemen Pendidikan dan Kebudayaan Direktorat Jendral Pendidikan Tinggi. Jakarta.

7. Sutantyo, E. 1991, Penentuan Kadar Air, Kadar Lemak dan Asam Sianida. Makalah Pelatihan Guru-Guru Akademi Gizi dalam Praktek Kimia Makanan. Jakarta.

8. Winarno, F.G. 1997, Kimia pangan dan Gizi. PT. Gramedia; Jakarta.

9. Sediaoetama, A. D. 1987, Ilmu Gizi Untuk Profesi dan Mahasiswa I dan II. Dian Rakyat; Jakarta. 